\section{ALBINO SANDHILL CRANE}

STAN SHADICK, 3F-1800 Main Street, Saskatoon, Saskatchewan. S7H 4B3

Following a successful trip north of Saskatoon 6 October 1984 to observe Whooping Cranes, Paul Coutu and I drove the tour group to the Outlook district, where they would be able to see many thousands of Sandhill Cranes congregating for the evening. The fields were indeed full of Sandhill Cranes and geese. A few young cranes were observed dancing with repeated jumps and much flapping of wings.

About half an hour before sunset, we noticed a white crane in a nearby flock of about 300 Sandhills. We stopped for further observation since there had been a Whooping Crane reported from the area. The bird appeared completely white except for a red forehead and brown wings. It lacked the dark cheeks of a whooper and stood exactly the same height as the other Sandhills. An adult Whooping Crane should have stood noticeably taller. Again, when the group of cranes flew to a night roost along the river, it was noted that the white bird was the same size as the other cranes. When flying it showed a white body and dark mottled wings with blackish primaries and secondaries. These features show clearly in photographs of the bird taken by Dr. Nigel Mathews of lle a la Crosse.

The possibility of the bird being a hybrid Sandhill X Whooping Crane was suggested. However Ernie Kuyt of the Canadian Wildlife Service advised that captive hybrids produced by artificial insemination in Patuxent Maryland were a light uniform gray all over. They were totally unlike the bird in the Mathews photograph. It is most likely that the white bird was a partial albino Sandhill Crane.

I wish to thank Paul Coutu, Jim Slimmon, Brian Johns and the Canadian Wildlife Service for their assistance with the society-run tours. Ernie Kuyt provided helpful information and comments on the manuscript.

\section{SAW-WHET OWL IN D'ARCY, SASKATCHEWAN}

\author{
CAROL C. CLARKE, Box 23, D'Arcy, \\ Saskatchewan. SOL ONO
}

On 6 November 1984, a Saw-Whet Owl flew into the D'Arcy Store when the owner let in her cat. It was very tame and sat on her husband's hand while he showed it to customers. Due to the traffic in the store, the cat, etc., the owl was placed in a bird cage for the night. The next day, it arrived at school. Because it had refused to eat any of the food offered, we decided that it should be released soon in a safe location away from the cats and dogs of town. Our retiring Unit Board Trustee, whose family had successfully raised a Great Horned Owl, came to our rescue. The owl was then released in an abandoned farm yard which contained large trees.

According to Renaud and Renaud's Birds of the Rosetown-Biggar District, Saw-Whet Owls are listed as "very rare vagrant visitant $^{\prime \prime}$. In their booklet only four sightings are recorded and all of these are east of D'Arcy in the Rosetown and Biggar districts.

Although no photographs were taken of this owl, it was identified by three birders as being a Saw-Whet.

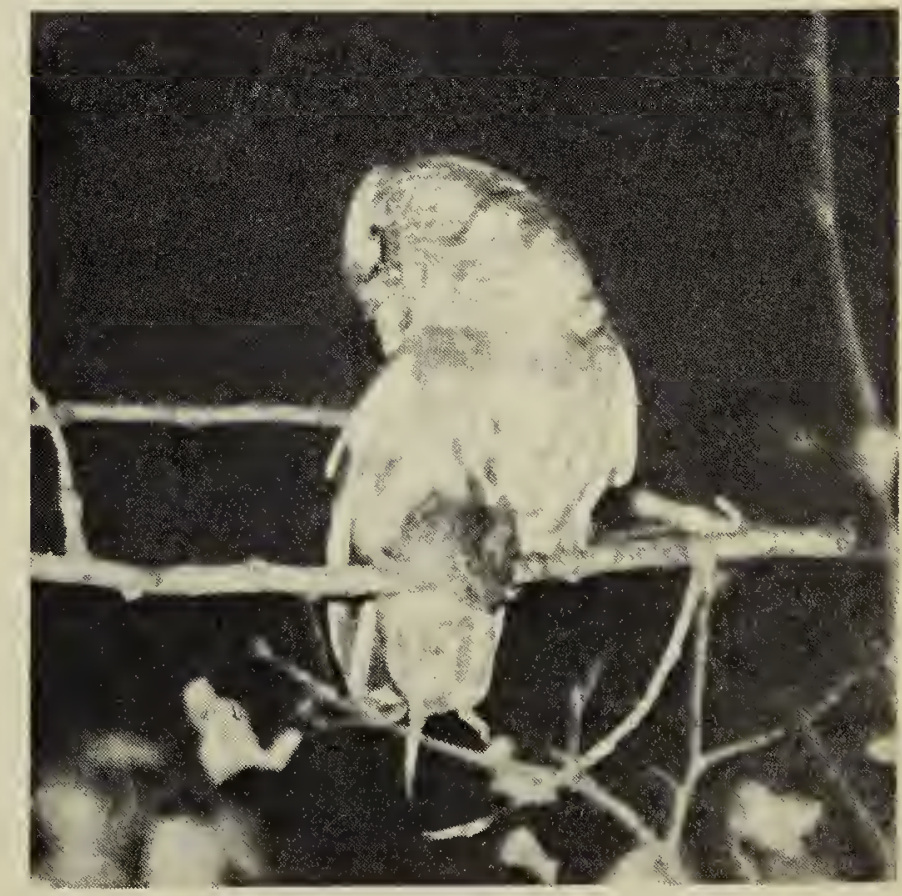

Saw-Whet Owl 